Authors' Contribution:

A Study Design

B Data Collection

C Statistical Analysis

D Data Interpretation

E Manuscript Preparation

F Literature Search

G Funds Collection

\title{
Local cryotherapy in tennis elbow (lateral epicodylitis)
}

\author{
Małgorzata Kawa ${ }^{\text {ABCDEFG, Małgorzata Kowza-Dzwonkowska } 2 \text { ABDEFG }}$ \\ ${ }^{1}$ Department of Physical Education, Faculty of Physiotherapy, Gdansk University of \\ Physical Education and Sport in Gdansk, Poland \\ 2 Department of Health Promotion, Faculty of Tourism and Recreation, Gdansk University \\ of Physical Education and Sport in Gdansk, Poland
}

\section{abstract}

Background The study investigated the analgesic effectiveness, the reduction in the intake of painkillers and an improvement in physical activity after local cryotherapy in tennis elbow (TE).

Material/Methods

The research group comprised patients of the Physiotherapy Patients diagnosed with so-called tennis elbow were referred to physical therapy treatments by specialist doctors. 34 patients were examined ( 26 women, 8 men), aged 36-59 years, who were then divided into two groups: Group X (17 persons) - treated with local cryotherapy (10 treatments over 2 weeks), Group Y (17 persons ) - the control group with no therapeutic procedures conducted for a period of 2 weeks. Materials for the quantitative analysis in the study were obtained by means of the Laitinen questionnaire and the VAS scale.

Results Results of the analysis showed significant differences between the intensity of pain experienced by the subjects, the range of received analgesics, and the difference in physical activity before the therapy and after its completion. Tests of scheduled comparisons showed a substantial decline in values among the subjects for both the combined therapy $(p=0.000)$ and local cryotherapy $(p=0.000)$.

Conclusions The analgesic effect of the combined therapy and local cryotherapy resulted in reducing the intake of analgesics and an improvement in physical activity of patients TE.

Key words lateral epicodylitis, tennis elbow, pain, cryotherapy

\section{article details}

Article statistics

Full-text PDF:

Copyright

Indexation:

Funding:

Conflict of interest: Corresponding author:

Open Access License:
Word count: 5,550; Tables: 8; Figures: 2; References: 41

Received: October 2014; Accepted: September 2015; Published: September 2015

http://www.balticsportscience.com

(c) Gdansk University of Physical Education and Sport, Poland

AGRO, Celdes, CNKI Scholar (China National Knowledge Infrastructure), CNPIEC, De Gruyter - IBR (International Bibliography of Reviews of Scholarly Literature in the Humanities and Social Sciences), De Gruyter - IBZ (International Bibliography of Periodical Literature in the Humanities and Social Sciences), DOAJ, EBSCO - Central \& Eastern European Academic Source, EBSCO - SPORTDiscus, EBSCO Discovery Service, Google Scholar, Index Copernicus, J-Gate, Naviga (Softweco, Primo Central (ExLibris), ProQuest - Family Health, ProQuest - Health \& Medical Complete, ProQuest - Illustrata: Health Sciences, ProQuest - Nursing \& Allied Health Source, Summon (Serials Solutions/ProQuest, TDOne (TDNet), Ulrich's Periodicals Directory/ulrichsweb, WorldCat (OCLC)

This research received no specific grant from any funding agency in the public, commercial, or not-for-profit sectors.

Authors have declared that no competing interest exists.

Mgr Małgorzata Kowza-Dzwonkowska, Pracownia SPA \& Wellness, Akademia Wychowania Fizycznego i Sportu im. J. Śniadeckiego w Gdańsku, ul. K. Górskiego 1, 80336 Gdańsk; phone no.: +48 58554 74 74; e-mail: mkd@awf.gda.pl

This is an open access article distributed under the terms of the Creative Commons Attribution-Non-commercial 4.0 International (http://creativecommons.org/licenses/by-nc/4.0/), which permits use, distribution, and reproduction in any medium, provided the original work is properly cited, the use is non-commercial and is otherwise in compliance with the license. 


\section{INTRODUCTION}

Tennis elbow, also known as lateral epicondylitis (LE), i.e. enthesopathy of the lateral epicondyle of the humerus (enthesopathia epicondyli lateralis humeri), is an inflammation of the insertion of tendons of the extensor muscles of the wrist at the lateral epicondyle of the humerus [1]. It is a consequence of overloading the muscles of wrist and fingers extensors and microdamage to muscle insertions at the epicondyle, which impairs performing daily functions, work or leisure activities [2]. Enthesopathy of the lateral elbow is one of many disorders of the musculoskeletal system, characterised by high resistance to treatment methods. The diversity of therapeutic ideas for chronic lateral elbow tendinopathy proved that continuous exploration of an effective procedure is necessary [3]. Tennis elbow is a common condition occurring in $3 \%$ of the total population $[4,5,6]$. The peak of LE incidence occurs between 30 and 60 years of age $[7,8]$. The risk of LE incidence and the highest rate of occurrence concerns professions in which repetitive, energetic movements of rotation, lifting and pressing are performed, such as among plumbers, painters, decorators, builders and gardeners. People working full-time at the computer keyboard are exposed in particular [9]. The pain is very strong during rotation, twisting, grasping and lifting movements $[10,11]$. Because most cases relate to the dominant hand, it has been reported that LE causes discomfort in daily activity and negatively affects the quality of life [12]. The upper extremity dysfunctions begin to appear during intensive work or injuries, and emerge with age.

Due to the complicated and complex structure, the elbow joint is one of the most susceptible to injuries. So-called "tennis elbow" is a painful condition which has its source in the pathologically affected area of the insertion of tendons of the extensor muscles of the wrist at the lateral epicondyle of the humerus [17]. The cause of degenerative changes usually lies in long-lasting muscle overload with repeated microdamage at their insertion to the bone. Pain appears on a small bony protrusion (epicondyle) on the lateral side of the elbow, where muscles extending fingers and the wrist are attached. The surface of this area is very small in relation to the stresses and tensions it endures during too intense muscle work [14, 15]. Figure 1 shows the place of pain in tennis elbow.

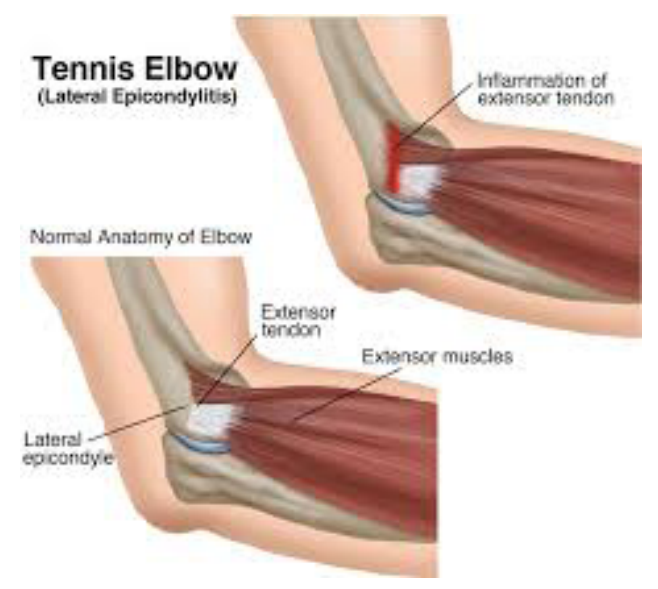

Fig 1. Place of pain in enthesopathy of the lateral compartment of the elbow. Retrieved from http://indiantrailpt.com/symptoms-conditions/tennis-elbow-lateral-epicondylitis 
According to the WHO definition, pain it is an unpleasant, sensory and emotional experience accompanying existing or potentially threatening damage to tissues, or only related to such damage. This definition stresses the biological and symptomatological function of pain in the system. It is an important reflexive-defensive factor. It warns a human being against the effects of external stimuli damaging a tissue, and at the same time it is one of the symptoms of a disease. Many a time it saves an organism from damage to a tissue or an organ. But it also happens that pain appears despite the lack of visible signals [18].

The pain is synonymous with both physical and mental suffering, perceived very individually. It is also often accompanied by the sympathetic nervous system symptoms, such as the accelerated heart rate or increased blood pressure. People differ in the so-called threshold pain. It is an effect of brain activity, which makes a pain stimulus easier or more difficult to bear. From the biological point of view, pain is a sensory experience, called nociceptive pain, emerging in the nerve endings, conductive tracks and perception areas in the brain $[19,20,21]$. In 1979 the Taxonomy Commission of International Study of Pain defined pain as an unpleasant sensory and emotional experience associated with the existing or potential tissue damage, or a sensation perceived as in the case of such damage [14]. According to Melzack, pain is a perceptive experience, the quality and the intensity of which is affected by the unique life story. This definition is more focused on the subjective feeling of pain, which is of a multidimensional character (nociception, perception, attitude to pain, suffering, pain expression) [22].

Today pain can be effectively treated and alleviated, and pain medicine is becoming an increasingly growing specialized field of medicine. The mechanisms of emergence and conduction of pain are nowadays even better understood, and with the development of new therapeutic techniques and modern medication, fighting pain is becoming more intentional, effective and safer for a patient.

Cryotherapy is a treatment method known and used for centuries. The history of treating with cold temperatures dates back to the Ancient times. The first mention of the use of low temperatures in medicine comes from Egypt 2500 BCE. Already then cold was viewed as an anaesthetic and antiinflammatory agent [23].

In the subject literature one can find many definitions of cryotherapy. According to Zagrobelny, cryotherapy is: "one of methods of medicinal application of cold. It is a physical therapy procedure, and so an application of a natural stimulus affecting a point, an area or the entire surfaces and limbs of the system, with an expectation that through the central nervous system the stimulus will trigger a beneficial response or reaction of a medical or regulatory nature. Clinically, cryotherapy is therefore a stimulating use of extremely low temperatures for 2-3 minutes to trigger and make use of physiological systemic reactions to cold and to assist the primary treatment and to facilitate treatment through movement" [24].

In line with the above, Sieron defines cryotherapy as "a stimulating surface use of cryogenic temperatures (below $-100^{\circ} \mathrm{C}$ ) in a short 
time of $120-180 \mathrm{~s}$ in order to provoke and use physiological responses to cold and to help the primary treatment and to facilitate healing through movement [25].

Księżopolska-Pietrzak presents a similar definition of cryotherapy. She claims that cryotherapy is "an application of the temperature below $-100^{\circ} \mathrm{C}$ for 2-3 minutes to the outer surface of the body in order to provoke and use physiological reactions to cold..." [26]. Spodaryk argues that "cryotherapy refers to the use of a physical stimulus lowering the temperature of tissues applied for medicinal purposes" [27].

The systemic or local application of cryogenic temperatures causes thermoregulation. Its initiation in the human body takes place by means of the nerve structures recording the temperature in time. Two groups of receptors are distinguished: thermoreceptors and thermoenteroreceptors. The former are external receptors located in the skin and used to receive thermal stimuli from the environment, while the latter control the temperature inside the body $[24,28]$.

The main effect of cold on the body is to reduce the skin temperature by a few degrees Celsius. As a result, the skin and the subcutaneous tissue temperature plummets. The temperature of muscles is also reduced, but at a much slower pace. This results from vasoconstriction which maintains for about a minute after the procedure. The blood flow and thermal conductivity in the surface tissues are reduced. Metabolism and the activity of endocrine glands are altered. There occurs so-called muscle tremor and reduction in metabolism by about $50 \%$, which in turn leads to a reduction in energy demands in tissues and connected with this decline in oxygen demand. On the other hand, after the treatment there is vasodilation and blood supply to the internal organs, which in turn leads to a reduction in the amount of lactate and histamine and alleviates pain. Lowering the body temperature leads to a reduction in the flow of nerve impulses. Another equally important effect of a prolonged influence of cold is an increase in the secretion of thyroid hormones and adrenal glands and an increased cell metabolism [29].

Speaking of treatment with cold, one should pay attention to the duration of a procedure. Thus during slow cooling down of tissues, there is a slowing down of the metabolic rate in the tissues, while in quick and short-time cooling down there is a hyperaemic reaction known as cryostimulation. The therapeutic effect of cryotherapy depends on the cooling rate, i.e., the time in which low temperature is achieved and on the time of its presence in the tissue [30].

Depending on the surface area affected by the therapy, cryotherapy is divided into local and whole-body cryotherapy. In local cryotherapy liquid nitrogen is the most commonly used agent, with the gas temperature at the nozzle being circa minus $160-190^{\circ}$ Celsius. For therapeutic purposes also a mixture of liquid nitrogen vapours and chilled atmospheric air is used, where the temperature at the nozzle is adjustable from $-100^{\circ} \mathrm{Celsius}$ to $-180^{\circ}$ Celsius. In local cryotherapy depending on the size and location 
of the treated area, the duration of one procedure ranges from 30 seconds to 3 minutes. Whole-body cryotherapy is performed in a chamber in which thanks to liquid nitrogen the therapeutic temperature is maintained within the limits of $-70^{\circ} \mathrm{C}$ to $-110^{\circ} \mathrm{Celsius}$. The duration of a single treatment is 30 seconds to 3 minutes. An important and integral part of the procedure is gymnastics after leaving the chamber [23, 24].

Equipment used in local cryotherapy (Fig. 2) acquires low temperature from liquid nitrogen, chilled air and carbon dioxide. Local cryotherapy relies on cooling down tissues by means of nitrogen vapours. Liquid nitrogen, whose boiling point is $-195.8^{\circ} \mathrm{C}$, after heating inside the tank changes into the gas form. The appearing difference in pressure between atmospheric pressure and the tank provokes the flow of nitrogen vapours from the tank to the hose finished with a nozzle. The gas temperature at the nozzle is approximately $-196^{\circ} \mathrm{C}$ to $-160^{\circ} \mathrm{C}[28]$.

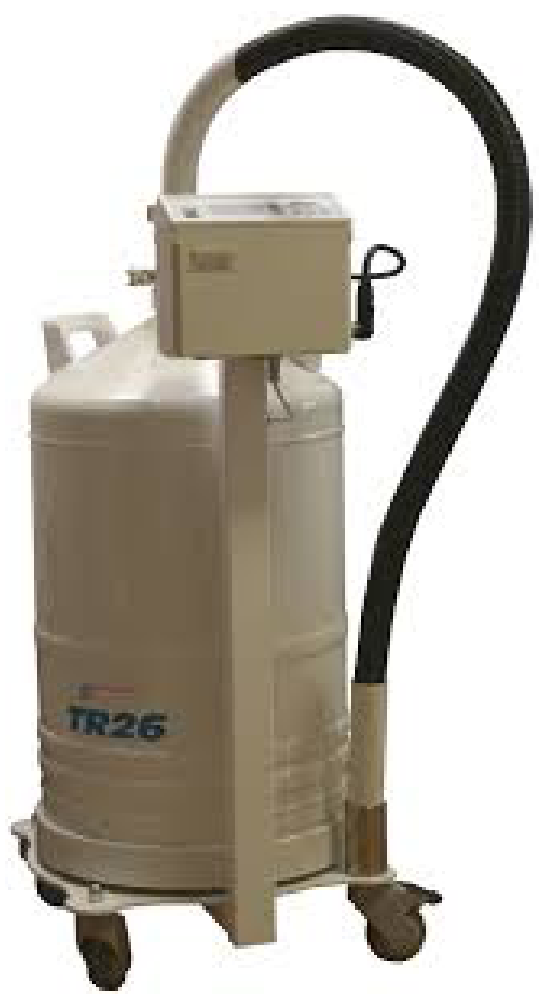

Fig 2. Device KRIOPOL R26 for local cryotherapy. Retrieved from http://tech.money.pl

One of the therapeutic effects of the application of treatment with cold is the pain alleviating effect. In the hitherto studies it was ascertained that cryotherapy causes pain relief, but studies defining the most effective methodology in different injuries and supporting biological regeneration are still needed. Researchers claim that the analgesic effect results from a reduction in the conductivity speed in sensory fibres. This effect lasts only until there is a reduction in the nervous tissue temperature down to $10-15^{\circ} \mathrm{C}$. This advantage of cryotherapy enables an earlier start of rehabilita-tion exercises. It facilitates performing these exercises because it inhibits pain and reduces muscle tone, and thus allows for faster healing of inflammations and wounds and has an anti-oedematous effect [13, 30, 31]. 
Boosting sensory receptors with cold causes painlessness in patients, cessation of the feeling of pain. This effect can maintain for hours, and if treatments are regularly repeated, it can keep up even for extended periods of time. This "stimulation analgesia" relies on blocking the flow of pain impulses in the spinal cord. Then the strongest pain stimulation does not occur, because pain impulses do not reach the cerebral cortex. In addition, the "the endogenous opioid system" is activated, which is responsible for producing $\beta$-endorphin, i.e. an endogenous morphine-like substance. Owing to the patient's not feeling pain, it is possible to increase in the intensity of kinesiotherapy even 3-4 times [32].

Extreme cold also reduces motor conduction. It blocks the motor nerve end-plate and dampens the reflex actions, especially of the spinal cord. Thanks to that muscle spasticity is reduced. Therefore, cryotherapy is recommended in patients with neurological diseases and orthopaedic injuries. It is used in the treatment of traumas, fractures, sprains, and dislocations. In addition, it is used in degenerative and rheumatic diseases (such as rheumatoid arthritis, rheumatic fever and ankylosing spondylitis) [29].

Many researchers stress that cryotherapy has a wide use in first aid and sports medicine rehabilitation. Cooling down should be applied immediately after the injury. This is one of the safest and simultaneously effective methods of reducing bruising, pain and inflammatory reactions, and it limits damage. Indications for the use of local cryotherapy involve its anti-oedematous, anti-inflammatory and tension-reducing influence [30, 31].

It can be concluded that cryotherapy is an invaluable method in the treatment of patients with many injuries and diseases in which the aim is to improve mobility [33], including the treatment of tennis elbow. Cryostimulation procedures shorten rehabilitation and accelerate recovery [24, 28].

\section{The AIM AND THE SUBJect MATTER OF THE STUdY}

The subject of the study was the analgesic efficacy of local cryotherapy in treating lateral elbow enthesopathy, while the aim was to evaluate its impact on improving the subjects' mobility and reducing the intake of pain-killing medication.

The conducted research falls into the explanatory and interpretation category. The authors attempted to find the relevance of assumptions as to the effectiveness of the combined analgesic therapy and local cryotherapy in the treatment of lateral elbow enthesopathy.

On this basis, the following research hypotheses were formulated:

1. Application of local cryotherapy reduces pain disorders in the studied patients with enthesopathy of the lateral elbow.

2. After applying local cryotherapy, there is an improvement in mobility of the patients with so-called tennis elbow.

3. Application of local cryotherapy contributes to a reduction in the intake of analgesics by the studied patients. 


\section{MATERIAL AND METHODS}

The research group was composed of patients of Physiotherapy and Wellness Centre "Gracilis" in Gdynia and the Physical Therapy Centre at Gdansk University of Physical Education and Sport. Patients diagnosed with enthesopathy of the lateral elbow (so-called tennis elbow) were referred to physiotherapeutic treatment by medical specialists: orthopaedists, traumatologists, specialists is med-ical rehabilitation. They were chosen deliberately and randomly.

The research was conducted on 34 patients of both sexes (26 women, 8 men), aged 36-59 years, who depending on the type of applied procedure were divided into two groups: Group X (17 persons) - treated with local cryotherapy and Group Y (17 persons) - the control group with no therapeutic procedures conducted for a period of 2 weeks. In each of these groups there were 13 women and 4 men, of whom 10 persons had higher education and 7 persons secondary education. An analysis of both groups subjects' age showed no significant differences (the mean age for the control group was 46.6 years (SD 5.8 years), and for the local cryotherapy group 45.9 years (SD 5.2), $\mathrm{p}=0.5395$ ).

In Group X local cryotherapy was applied to each patient in the number of 10 treatments over a period of 2 weeks from Monday to Friday. The treatments were performed with a local cryotherapy device Kriopol R-26 with liquid nitrogen, directed at the place of pain for 1 to 3 minutes. The procedure was performed on clean, dry skin in a seated position. The nozzle of the cryostimulation device was positioned at a distance of $3 \mathrm{~cm}$, in close cooperation with the patient.

The study used the method of a diagnostic survey and the statistical method. Materials for the quantitative analysis in the study were obtained by means of the Laitinen questionnaire and the Visual-Analogue Scale by Barbara Headley (VAS) [34].

Measurements of the characteristics of pain were performed using two scales:

1. the modified Laitinen questionnaire of indicators of pain - immediately before and after the therapy the subjective assessment of pain (the intensity and frequency rated on a 5-point scale) was evaluated. The questionnaire was completed in accordance with the patient's subjective feelings.

2. the Visual-Analogue scale (VAS) for graphical and numerical description of the perceived pain. On a line of about $10 \mathrm{~cm}$ in length, with marked only the beginning and end, the patient identified a point which corresponded to the intensity of his feeling of pain (a condition with no pain was marked as " 0 " and with the strongest imaginable pain "10". The results of the intensity of pain were measured in millimetres: from 0 to $100 \mathrm{~mm}$ ).

The VAS scale used in the study helps to assess the intensity of pain. However, it should be noted that this isolated feature does not characterize the very complex phenomenon of pain and, above all, does not describe the degree of a patient's efficiency. Scales of the self-assessment of motor activity, whose results coincide with the so-called pain behaviours, seem much more useful to this effect. Therefore, Laitinen's questionnaire was additionally used [46]. 
To verify the significance of differences between groups in which the different types of treatments were applied, the ANOVA variance analysis tool with repeated measures was used. The model assumptions about the homogeneity of variance and covariance were verified by means of the following tests: Cochran, Hartley, Bartlett and Box. The analysis was performed with a use of MS Excel spreadsheet and Statistica software.

\section{RESULTS}

The table below (Tab. 1) shows the mean value and the standard deviation of the tested components of pain sensations in comparison to the situation before the study and after its completion. In the local cryotherapy group a statistically significant decrease in pain values was observed. In the control group statistically significant results were not revealed, despite their small reduction. A slight drop in pain values can be explained by the spontaneous healing process of inflammatory lesions. In the subsequent tables the results of similar variables from the two used questionnaires evaluating pain were compiled.

Table 1. Mean value and standard deviation of individual components of feeling pain

\begin{tabular}{|c|c|c|c|c|c|}
\hline \multirow{3}{*}{ No. } & \multirow{3}{*}{ Variable } & \multicolumn{2}{|l|}{$\begin{array}{l}\text { Group } \\
\text { control }\end{array}$} & \multicolumn{2}{|c|}{$\begin{array}{l}\text { Group } \\
\text { local cryotherapy }\end{array}$} \\
\hline & & before & after & $\begin{array}{l}\text { before } \\
\text { treatment }\end{array}$ & $\begin{array}{l}\text { after } \\
\text { treatment }\end{array}$ \\
\hline & & $\overline{\mathrm{x}} \pm \mathrm{SD}$ & $\overline{\mathrm{x}} \pm \mathrm{SD}$ & $\bar{x} \pm S D$ & $\overline{\mathrm{x}} \pm \mathrm{SD}$ \\
\hline 1 & the degree of pain & $5.35 \pm 2.15$ & $5.11 \pm 2.47$ & $5.35 \pm 1.73$ & $2.76 \pm 1.56$ \\
\hline 2 & pain at night & $2.82 \pm 1.59$ & $2.70 \pm 1.43$ & $2.76 \pm 1.35$ & $1.76 \pm 0.97$ \\
\hline 3 & impaired motor activity due to pain & $3.59 \pm 1.28$ & $3.29 \pm 0.99$ & $3.06 \pm 1.52$ & $1.35 \pm 1.06$ \\
\hline 4 & the use of painkillers & $2.41 \pm 1.33$ & $2.10 \pm 0.89$ & $2.35 \pm 1.46$ & $1.18 \pm 0.95$ \\
\hline 5 & $\begin{array}{l}\text { pain interfering with household } \\
\text { chores }\end{array}$ & $2.47 \pm 1.12$ & $2.22 \pm 1.04$ & $2.71 \pm 1.4$ & $1.06 \pm 0.83$ \\
\hline 6 & pain interfering while driving a car & $2.71 \pm 1.45$ & $2.35 \pm 1.20$ & $1.82 \pm 1.42$ & $0.88 \pm 0.86$ \\
\hline 7 & change of job duties due to pain & $2.00 \pm 1.22$ & $1.62 \pm 0.96$ & $1.65 \pm 1.37$ & $0.76 \pm 0.97$ \\
\hline 8 & pain control & $2.29 \pm 1.76$ & $1.82 \pm 1.28$ & $2.41 \pm 1.70$ & $0.53 \pm 0.80$ \\
\hline 9 & $\begin{array}{l}\text { control other aspects of life due to } \\
\text { pain }\end{array}$ & $2.47 \pm 1.62$ & $2.12 \pm 1.78$ & $2.47 \pm 1.55$ & $0.76 \pm 0.83$ \\
\hline 10 & intensity of pain & $2.35 \pm 0.7$ & $2.20 \pm 0.64$ & $2.18 \pm 0.81$ & $1.12 \pm 0.78$ \\
\hline 11 & frequency of pain & $1.88 \pm 0.78$ & $1.74 \pm 0.56$ & $1.53 \pm 0.62$ & $0.71 \pm 0.47$ \\
\hline 12 & use of medicinal painkillers & $1.29 \pm 1.05$ & $1.03 \pm 0.91$ & $1.24 \pm 0.66$ & $0.47 \pm 0.51$ \\
\hline 13 & limitation of physical activity & $1.71 \pm 0.92$ & $1.65 \pm 0.99$ & $1.29 \pm 1.05$ & $0.65 \pm 0.79$ \\
\hline
\end{tabular}

\section{VARIABle: INTENSITY OF PAIN (VAS SCALE)}

ANOVA analysis of variance with repeated measures for the variable "Intensity of pain (VAS scale)" revealed a statistically significant effect of participation in local cryotherapy treatments. The mean values of the intensity of pain relative to the state before and after the study are presented in Tab. 2 . 
Table 2. Mean value of the degree of pain

\begin{tabular}{lllll}
\hline & Group & Time & $\begin{array}{l}\text { Mean } \\
\text { value }\end{array}$ & $\mathrm{N}$ \\
\hline 1 & group control & the degree of pain - before & 5.35 & 17 \\
\hline 2 & group control & the degree of pain - after & 5.11 & 17 \\
\hline 3 & group local cryotherapy & the degree of pain - before treatment & 5.35 & 17 \\
\hline 4 & group local cryotherapy & the degree of pain - after treatment & 2.76 & 17 \\
\hline
\end{tabular}

The results of the analysis showed significant differences between the intensity of pain (VAS scale) felt by the subjects prior to the therapy and its intensity after its completion. Tests of scheduled comparisons showed a marked decline in values of the felt intensity of pain after local cryotherapy $(p=0.000)$. The degree of change in the intensity of pain (VAS scale) among the subjects after fin-ishing treatments is presented in Tab. 3 .

Table 3. The degree of change in pain intensity (VAS scale).

\begin{tabular}{lllll}
\hline The degree of change in pain intensity & $\begin{array}{l}\text { Group local } \\
\text { cryotherapy }\end{array}$ & $\% \mathrm{~N}$ & $\begin{array}{l}\text { Group } \\
\text { control }\end{array}$ & $\% \mathrm{~N}$ \\
\hline No change & 2 & $11.8 \%$ & 15 & $88.2 \%$ \\
\hline Moderate decline (a decrease of 2-3 points) & 11 & $64.7 \%$ & 2 & $11.8 \%$ \\
\hline A big drop (a decrease of 4-5 points) & 4 & $23.5 \%$ & 0 & $0 \%$ \\
\hline Total in the group (N) & 17 & $100.0 \%$ & 17 & $100 \%$ \\
\hline
\end{tabular}

\section{VARIABLE: INTENSITY OF PAIN (LAITINEN SCALE)}

The mean values of the intensity of the pain - Laitinen scale (relative to the state before and after the study are presented in Tab. 4.

Table 4. Mean value the intensity of pain - Laitinen scale.

\begin{tabular}{lllll}
\hline No. & Group & Time & Mean value & N \\
\hline 1 & group control & intensity of pain - before & 2.35 & 17 \\
\hline 2 & group control & intensity of pain - after & 2.20 & 17 \\
\hline 3 & group local cryotherapy & intensity of pain - before treatment & 2.18 & 17 \\
\hline 4 & group local cryotherapy & intensity of pain - after treatment & 1.12 & 17 \\
\hline
\end{tabular}

The results of the analysis showed significant differences between the scope of the intensity of pain prior to the therapy and after its completion. Tests of scheduled comparisons showed a significant decrease in the intensity of pain after local cryotherapy $(\mathrm{p}=0.000)$.

\section{VARIABLE: INTAKE OF ANALGESICS (VAS)}

ANOVA analysis of variance with repeated measures for the variable "Intake of analgesics (VAS)" revealed a statistically significant effect of participation in the therapy (a comparison of the situation before and after the therapy. The mean values of the intake of analgesics (VAS) relative to the state before and after the study are presented in Tab. 5 . 
Table 5. Mean value of the intake of analgesics (VAS scale)

\begin{tabular}{lllll}
\hline No. & Group & Time & Mean value & N \\
\hline 1 & group control & intensity of pain - before & 2.41 & 17 \\
\hline 2 & group control & intensity of pain - after & 2.10 & 17 \\
\hline 3 & group local cryotherapy & intensity of pain - before treatment & 2.35 & 17 \\
\hline 4 & group local cryotherapy & intensity of pain - after treatment & 1.18 & 17 \\
\hline
\end{tabular}

The analysis results showed significant differences between the scope of using painkillers before the beginning of the therapy and after its completion. Tests of scheduled comparisons showed a significant decrease in the range of using painkillers after local cryotherapy $(\mathrm{p}=0.000)$.

\section{VARIABLE: INTAKE OF ANALgESICS (LAITINEN SCALE)}

ANOVA analysis of variance with repeated measures for the variable "Intake of analgesics" revealed a statistically significant effect of participation in local cryotherapy treatments. Mean val-ues of the intake of analgesics relative to the state before and after the study are presented in Tab. 6 .

Table 6. Mean value of the intake of analgesics (Laitinen scale)

\begin{tabular}{lllll}
\hline No. & Group & Time & Mean value & N \\
\hline 1 & group control & use of medicinal painkillers - before & 1.29 & 17 \\
\hline 2 & group control & use of medicines painkillers - after & 1.03 & 17 \\
\hline 3 & group local cryotherapy & use of medicines painkillers - before treatment & 1.24 & 17 \\
\hline 4 & group local cryotherapy & use of medicines painkillers - after treatment & 0.47 & 17 \\
\hline
\end{tabular}

The analysis results showed significant differences between the range of using analgesics before the beginning of the therapy and after its completion. Tests of scheduled comparisons showed a significant decrease in the range of using painkillers after local cryotherapy $(p=0.000)$.

\section{VARIABLE: ImpaiRed PHYSICAL ACTIVITY dUE tO PAIN (VAS SCALE)}

ANOVA analysis of variance with repeated measures for the variable "Impaired physical activity due to pain (VAS scale)" revealed a statistically significant effect of participation in local cryotherapy treatments. Mean values of impaired physical activity due to pain relative to the state before and after the study are presented in Tab. 7.

Table 7. Mean value of impaired motor activity due to pain

\begin{tabular}{|c|c|c|c|c|}
\hline No. & Group & Time & $\begin{array}{l}\text { Mean } \\
\text { value }\end{array}$ & $\mathrm{N}$ \\
\hline 1 & group control & impaired motor activity due to pain - before & 3.59 & 17 \\
\hline 2 & group control & impaired motor activity due to pain - after & 3.29 & 17 \\
\hline 3 & group local cryotherapy & $\begin{array}{l}\text { impaired motor activity due to pain } \\
\text { - before treatment }\end{array}$ & 3.06 & 17 \\
\hline 4 & group local cryotherapy & $\begin{array}{l}\text { impaired motor activity due to pain } \\
\text { - after treatment }\end{array}$ & 1.35 & 17 \\
\hline
\end{tabular}


The analysis results showed significant differences between the perceived impaired physical activity due to pain before the study and the degree of impairment experienced after its completion.

\section{VARIABLE: LIMITATION OF PHYSICAL ACTIVITY (LAITINEN SCALE)}

ANOVA analysis of variance with repeated measures for the variable "Limitation of physical activity (Laitinen scale)" revealed a statistically significant effect of participation in local cryotherapy treatments. Mean values of limitation of physical activity (Laitinen scale) relative to the state before and after the study are presented in Tab. 8.

Table 8. Mean value of impaired motor activity due to pain

\begin{tabular}{llllc}
\hline No. & Group & Time & Mean & $\mathrm{N}$ \\
\hline 1 & group control & limitation of physical activity - before & 1.71 & 17 \\
\hline 2 & group control & limitation of physical activity - after & 1.65 & 17 \\
\hline 3 & group local cryotherapy & limitation of physical activity - before treatment & 1.29 & 17 \\
\hline 4 & group local cryotherapy & limitation of physical activity - after treatment & 0.65 & 17 \\
\hline
\end{tabular}

The analysis results showed significant differences between the scope of the limitation of physical activity before the therapy and after its completion. Tests of scheduled comparisons revealed a significant decrease in limitations of physical activity after local cryotherapy $(\mathrm{p}=0.0015)$.

\section{DISCUSSION}

Enthesopathy of the lateral elbow is one of frequent pain syndromes in the upper extremity. It is the pain in the area of the lateral elbow joint that makes patients see medical specialists. It limits physical activity in the execution of manual activities of both everyday life and professional and recreational activities as well as induces taking painkillers. Damage to the locomotor system does not heal without trace and manifests itself in the form of dysfunctions or discomforts worsening with time. The treatment which is usually taken too late does not ensure healing of the injury. However, if treated in time and in a thoughtful way, it is usually successful $[35,36]$.

The Authors' own research gave an opportunity to evaluate the effectiveness of a combined analgesic therapy and local cryotherapy, their impact on reducing the intake of analgesics and the assessment of physical activity in a group of 34 patients with the tennis elbow syndrome.

The conducted research shows that treatment with cold (cryotherapy) is applicable in treating pain disorders of the lateral elbow. ANOVA analysis of variance with repeated measures for the variable "intensity of pain" (the VAS scale and the Laitinen scale) revealed a statistically significant effect of participation in treatments (a comparison of the situation before the therapy and after its comple-tion). After the application of a series of treatments of local cryotherapy in the group of subjects, there was a moderate decrease in pain among $64.7 \%$ of the subjects according to the VAS and among $76.5 \%$ of the subjects according to the Laitinen scale. A significant decrease in pain was analogously felt by $23.5 \%$ of patients according to both scales. Metzger and 
Zwingmann obtained similar results. They found maintenance of the analgesic effect shortly after completing the treat-ments and claimed that the effects of cold were then the most strongly expressed [37]. Skrzek and Zagrobelny in their research on the influence of cryotherapy on the locomotor activity also observed a very pronounced decrease in pain ailments and an improvement in joint mobility [24].

Cryotherapy affects the hypothalamus-pituitary-adrenal system, which is expressed in a significant increase in corticosteroids. Indirectly this proves an increased level of steroids in blood, which enables reducing the intake of pain killers or giving them up completely [24,38]. There are few papers regarding the research on taking analgesic medication after physical therapy treatments. The results of a study conducted by Wójcik and Tomczak on the application of local cryotherapy to decrease pain and reduce the use of analgesics indicate that cold has an influence on reducing the use of pharmacotherapy. Before the treatment $50 \%$ of the subjects had used medication, and after a series of local cryotherapy treatments, the number decreased by half [39]. Similar conclusions can be drawn on the basis of results of the present author's own research on patients with so-called tennis elbow. An analysis of study results both according to the VAS scale and the Laitinen scale showed significant differences between the intake of painkillers before the therapy and after its completion. Tests of scheduled comparisons revealed a significant decrease in values for local cryotherapy $(p=0.000)$. The subjects limited or came off analgesics.

In addition to pharmacological therapy, doctors and patients are looking for other methods to overcome pain which may cause physical activity restrictions. Księżopolska-Pietrzak and Samborski believe that the use of cryotherapy improves the patients' health status by reducing pain in the affected joints, which has a positive impact on improving motor activity [24, 40]. The results obtained in this study confirm the importance of local cryotherapy in the improvement of physical activity of patients with so-called tennis elbow. Interpretation of results according to the VAS scale and the Laitinen questionnaire suggests beneficial effects of local cryotherapy increasing motor activity. After a series of treatments an improvement in motor activity was reported by $70.6 \%$ (VAS scale) and $76.4 \%$ (Laitinen scale) of the studied patients.

A combined therapy is an alternative to local cryotherapy treatment of the lateral elbow disorders. Medical devices to perform treatments of the combined therapy in one piece of equipment have been available on the market for several years. A combination of two forms of energy, i.e. modulated current of medium frequency and ultrasounds, created a stimulus with a strong analgesic effect [41]. The use of combined therapy treatments in own studies as a method reducing pain ailments in the lateral elbow syndrome yielded effective results (as confirmed by the examined patients in subjective and objective assessments). The analysis results showed significant differences between the scope of the intensity of pain according to the VAS scale and the Laitinen scale before and after the therapy. As a result of the application of the combined therapy in the group of subjects, there was a moderate decrease in pain - according to VAS among $76.5 \%$ of the subjects and according to the Laitinen scale among $82.4 \%$ of the subjects. A significant decrease in pain was analogously felt by $23.5 \%$ of the subjects on the VAS scale and by $17.6 \%$ on the Laitinen scale. 
Similar studies were conducted by Korabiewska, Sipko, Lewandowska, and Białoszewski [16]. Before treatments subjects with so-called tennis elbow had identified their pain as strong in 55\% and as moderate in $45 \%$ of the cases, while after a combined therapy - as moderate in $20 \%$ and as mild in $20 \% .20 \%$ of all subjects felt no pain at all. The same group of researchers evaluated the role of the combined therapy in reducing the intake of analgesics. The interpretation of the results obtained on the patients examined in this study is similar to the results obtained by the above mentioned researchers. Analysing the VAS scale and on the basis of the Laitinen questionnaire, one can assume beneficial analgesic effects of the combined therapy. After application of treatments, a reduction in the use of painkillers and an increase in physical activity was found. After a series of treatments more than half of the patients, i.e. 52.9\% (the VAS scale) and 53\% (the Laitinen scale) limited their intake of painkillers; the improvement in motor activity was analogously reported by $70.6 \%$ of the subjects (the VAS scale) and $76.4 \%$ (the Laitinen scale).

Research on the comparison of the effectiveness of physical therapy procedures in treating pain disorders were conducted by Krawczyk-Wasielewska, Kuncewicz, Sobieska, and Samborski [41]. They demonstrated that cryotherapy, laser and ultrasounds are among the most effective procedures. Patients' subjective assessment was comparable as to the analgesic effect, reduction in the use of pain-killers and the improvement in motor activity. Own research demonstrated a lack of a significant interaction effect in all the examined variables in application of local cryotherapy and the combined therapy. This does not entitle a statement that one of the applied types of procedures proved to be more effective in this regard than the other in treating the lateral elbow.

Evaluation of results of the treatment confirms the legitimacy of using the combined therapy and local cryotherapy in the treatment of enthesopathy of the lateral elbow. However, further studies and observations of the effectiveness of the therapy on a larger population of subjects are necessary in order to obtain information on the period of the achieved improvement and its effects on the body.

\section{CONCLUSIONS}

Local cryotherapy influences reducing the pain intensity in the examined patients. Local cryotherapy treatments affected the intake of analgesics among the studied patients and improved their motor activity.

\section{REFERENCES}

[1] Mahanta V, Dudhamal TS, Gupta SK. Management of tennis elbow by Agnikarma. J Ayurveda Integr Med. 2013;4(1):45

[2] Stasinopoulos D, Johnson MI. "Lateral elbow tendinopathy" is the most appropriate diagnostic term for the condition commonly referred to as lateral epicondylitis. Med Hypotheses. 2006;67(6):1400-1402.

[3] Robinson J, Hoens A, Scott A. Treatment options for tennis elbow. Br Columbia Med J. 2013 Oct;55(8):381393.

[4] Asssendelft W, Green S, Stuijs P, Smidt N. Tennis elbow. [BMJ. 2003] - PubMed - NCBI. [cited 2014 Jul 23]; Available from: http://www.ncbi.nlm.nih.gov/pubmed/12907489/

[5] Hamilton PG. The prevalence of humeral epicondylitis: a survey in general practice. [cited 2014 Jul 24]. Available from: http://bjgp.org/content/36/291/464.full.pdf+html

[6] Shiri R, Viikari-Juntura E, Varonen H, Heliövaara M. Prevalence and determinants of lateral and medial epicondylitis: a population study. Am J Epidemiol. 2006;164(11):1065-1074. 
[7] Smidt N, Lewis M, Windt DAVD, Hay EM, Bouter LM, Croft P. Lateral epicondylitis in general practice: course and prognostic indicators of outcome. J Rheumatol. 2006;33(10):2053-2059.

[8] Vicenzino B, Wright A. Lateral epicondylalgia I: epidemiology, pathophysiology, aetiology and natural history. Phys Ther Rev. 1996;1(1):23-34.

[9] Village J, Frazer M, Cohen M, Leyland A, Park I, Yassi A. Electromyography as a measure of peak and cumulative workload in intermediate care and its relationship to musculoskeletal injury: an exploratory ergonomic study. Appl Ergon. 2005;36(5):609-618.

[10] Van Rijn RM, Huisstede BM, Koes BW, Burdorf A. Associations between work-related factors and specific disorders at the elbow: a systematic literature review. Rheumatology. 2009 May;48(5):528-36.

[11] Geoffroy P, Yaffe MJ, Rohan I. Diagnosing and treating lateral epicondylitis. Can Fam Physician. 1994;40:73.

[12] Halle JS, Franklin RJ, Karalfa BL. Comparison of Four Treatment Approaches for Lateral Epicondylitis of the Elbow. J Orthop Sports Phys Ther. 1986;8(2):62-69.

[13] Czopik J. Profilaktyka i leczenie urazów w tenisie [Prevention and treatment of injuries in tennis]. Warszawa: Atena; 2005. Polish.

[14] Domżała TM. Ból - podstawowy objaw w medycynie [Pain - the primary symptom in medicine]. Warszawa: Wyd. Lekarskie PZWL; 1996. Polish.

[15] Pain in chronic pancreatitis: a salutogenic mechanism or maladaptive brain response? Pancreatology. 2007;411-22.

[16] Korabiewska I, Sipko H, Lewandowska M, Białoszewski D. Ocena skuteczności leczenia falą uderzeniową i terapia skojarzoną pacjentów z tzw. „łokciem tenisisty” [Evaluation of effective-ness shock wave therapy and combination therapy patients with „Tennis elbow”]. In: XXII Kongres Balneologiczny. Połczyn Zdrój; 2010. Polish.

[17] Walz DM, Newman JS, Konin GP, Ross G. Epicondylitis: Pathogenesis, Imaging, and Treatment 1. Radiographics. 2001;30(1):167-184

[18] Romanowski M, Rąglewska P. Sposoby leczenia bólu w subiektywnej ocenie pacjentów z chorobami zwyrodnieniowymi stawów [Methods of treating pain in the subjective evaluation of patients with degenerative diseases of joints]. Prakt Fizjoterapia Rehabil. 2010;5(10):46-49. Polish.

[19] Filipczak-Bryniarska I, Bryniarski K, Woroń J, Wordliczek J. Mechanizmy przewodzenia bólu. Rola układy odpornościowego w regulacji odczuwania bólu [Mechanisms of conducting pain. The role of the immune system in regulating the feeling of pain]. Anestezjol Ratow. 2010;4:500-509. Polish.

[20] Kumar K, Rizvi S. Historical and present state of neuromodulation in chronic pain. Curr Pain Headache Rep. 2014;18(1):1-7.

[21] Meirinhos T, Aguiar R, Ambrósio C, Barcelos A. Neuropathic pain in rheumatic diseases: a cross-sectional study. Ann Rheum Dis. 2014;73(Suppl 1):A76-A76.

[22] Weisberg J, Shink H. Zwyciężać ból [Overcoming pain]. Warszawa: Bellona; 2006. Polish.

[23] Zagrobelny Z. Krioterapia miejscowa i ogólnoustrojowa [Local and whole-body cryotherapy]. Wrocław: Medyczne Urban\&Partner; 2003. Polish.

[24] Sieroń A, Cieślar G. Krioterapia - leczenie zimnem [Cryotherapy - treating with cold]. Bielsko-Biała: Alfa Medica Press; 2007. Polish.

[25] Księżopolska-Pietrzak K. Miejsce krioterapii w leczeniu chorób narządu ruchu-mechanizm działania, wskazania i przeciwwskazania [The place of cryotherapy in treating diseases of the locomotor system - mechanism of action, indications and contraindications]. Acta Bio-OptInformMed. 1996;2(3-4):157-160. Polish.

[26] Mika T. Fizykoterapia. Podręcznik wydziałów fizjoterapii medycznych studiów zawodowych [Physical therapy. Manual for physiotherapy departments of undergraduate medical studies]. Vol.III. Warszawa: PZWL; 1999. Polish.

[27] Straburzyńska-Lupa A, Straburzyński G. Fizjoterapia [Physiotherapy]. Warszawa: PZWL; 2006. Polish.

[28] Gregorowicz H, Dalidowski R. Krioterapia ogólnoustrojowa - jako metoda wspomagajaca farmakologiczne leczenie chorób narządu ruchu [Whole-body cryotherapy as a method supporting the pharmacological treatment of the locomotor system diseases]. Mag Med Rodz Ogólnej. 2006;(1):23-26. Polish.

[29] Gawroński W. O krioterapii raz jeszcze [On cryotherapy once more]. Med Sport. 2003;(7):151-155. Polish.

[30] Tomaszewki W, KurekJ. Krioterapia - skuteczna metoda w leczeniu i rehabilitacji urazów i schorzeń narządu ruchu [Cryotherapy - an effective method in treating and rehabilitating injuries and ailments of motor organs]. Med Sport. 1993;(9). Polish.

[31] Bauer J, Skrzek A. Fizjologiczne podstawy krioterapii [Physiological basics of cryotherapy]. Med Sport. 1999;94(6):3-7. Polish.

[32] Laitinen J. Acupuncture and transcutaneous electric stimulation in the treatment of chronic sacro-lumbalgia and ischialgia. Am J Clin Med. 1976;(4):168.

[33] Giemza C, Matczak-Giemza M, Ostrowska B, Bieć E, Doliński M. Effect of cryotherapy on the lumbar spine in elderly men with back pain. Aging Male. 2013 Dec 5;17(3):183-188.

[34] Kamper SJ. Pain Intensity Ratings. J Physiother. 2012;58(1):61.

[35] Buckup K. Testy kliniczne w badaniu kości, stawów i mięśni [Clinical tests in examining bones, joints and muscles]. Warszawa: PZWL; 2002. Polish.

[36] Metzger D, Zwingmann C. Whole body cryotherapy in rehabilitation of patients with rheumatic diseases pilot studies. Rehabilitation (Stuttg). 2000;(39):93-100.

[37] Zagrobelny Z, Zimmer K. Zastosowanie temperatur kriogenicznych w medycynie i fizjoterapii sportowej [The use of cryogenic temperatures in sports medicine and physiotherapy]. Med Sport. 1999;(5):8-9. Polish. 
[38] Biegański PP, Słomko W, Dzierżanowski M, Polewska E. Physiotherapy in Rheumatoid Arthritis. J Health Sci. 2013;3(6):295-304.

[39] Samborski W. Niefarmakologiczne metody leczenia bólu w reumatologii [Non-pharmacological methods of treating pain in rheumatology]. 2007;(3):20. Polish.

[40] Parada-Turska J, Szczepański L. Zespoły bólowe tkanek miękkich okolicy stawu łokciowego [Pain syndromes of the soft tissues at the elbow joint]. Rematologia. 1999;37(1):98-101. Polish.

[41] Krawczyk-Wasilewska A, Kuncewicz E, Sobieska M, Sambowski W. Ocena skuteczności fizykoterapii w uśmierzaniu bólu towarzyszącego reumatoidalnemu zapaleniu stawów [An assessment of the effectiveness of physical therapy in alleviating pain accompanying rheumatoid arthritis]. Nowa Med. 2007;(4):74-79. Polish.

Cite this article as: Kawa M, Kowza-Dzwonkowska M.

Local cryotherapy in tennis elbow

Balt J Health Phys Act 2015; 7(3): 73-87 